\title{
The role of dietary calcium in bone health
}

\author{
Albert Flynn \\ Department of Food and Nutritional Sciences, University College, Cork, Republic of Ireland
}

\begin{abstract}
Approximately $99 \%$ of body $\mathrm{Ca}$ is found in bone, where it serves a key structural role as a component of hydroxyapatite. Dietary requirements for $\mathrm{Ca}$ are determined by the needs for bone development and maintenance, which vary throughout the life stage, with greater needs during the periods of rapid growth in childhood and adolescence, during pregnancy and lactation, and in later life. There is considerable disagreement between expert groups on the daily $\mathrm{Ca}$ intake levels that should be recommended, reflecting the uncertainty in the data for establishing Ca requirements. Inadequate dietary $\mathrm{Ca}$ in early life impairs bone development, and $\mathrm{Ca}$ supplementation of the usual diet for periods of $\leq 3$ years has been shown to enhance bone mineral status in children and adolescents. However, it is unclear whether this benefit is long term, leading to the optimisation of peak bone mass in early adulthood. In later years inadequate dietary $\mathrm{Ca}$ accelerates bone loss and may contribute to osteoporosis. Ca supplementation of the usual diet in post-menopausal women and older men has been shown to reduce the rate of loss of bone mineral density at a number of sites over periods of 1-2 years. However, the extent to which this outcome reduces fracture risk needs to be determined. Even allowing for disagreements on recommended intakes, evidence indicates that dietary $\mathrm{Ca}$ intake is inadequate for maintenance of bone health in a substantial proportion of some population groups, particularly adolescent girls and older women.
\end{abstract}

Dietary calcium: Bone health: Life stage

$\mathrm{Ca}$, which accounts for $1-2 \%$ of the adult human body weight, is a major component of mineralised tissues, which contain $>99 \%$ of the total body $\mathrm{Ca}$. $\mathrm{Ca}$ is required for normal growth, development and maintenance of the skeleton, where it provides strength and structure. The remainder is present in blood, extracellular fluid, muscle and other tissues, where it plays a role in mediating vascular contraction and vasodilation, muscle contraction, nerve transmission and glandular secretion (Institute of Medicine, 1997).

As bone contains a high proportion of the body $\mathrm{Ca}$ and is the major reservoir for $\mathrm{Ca}$, its development and maintenance are the major determinant of $\mathrm{Ca}$ needs. Thus, unlike other nutrients, the requirement for $\mathrm{Ca}$ relates not to the maintenance of the metabolic function of the nutrient but to the maintenance of an optimal reserve and the support of the reserve's function (i.e. providing structural rigidity to the skeleton; Heaney, 1997). Ca requirements vary throughout an individual's life, with greater needs during the periods of rapid growth in childhood and adolescence, during pregnancy and lactation, and in later life.
$\mathrm{Ca}$ is a threshold nutrient, i.e. at suboptimal intakes the ability of the body to store $\mathrm{Ca}$ as bone tissue is limited by the intake of $\mathrm{Ca}$, but increasing $\mathrm{Ca}$ intake above that required as optimal for genetic or mechanical purposes does not result in further increases in stores (Heaney, 1997). Thus, Ca can only be stored as bone, and increasing $\mathrm{Ca}$ intake above that which produces optimal bone mass will not result in more bone.

There are important genetic and environmental influences on $\mathrm{Ca}$ requirements. Genetic influences include such factors as bone architecture and geometry, and responsiveness of bone to hormones that mediate the function of bone as the body's Ca reserve (Heaney, 1997). Environmental influences include factors such as dietary constituents and the extent of mechanical loading imposed on the skeleton in everyday life. As a result of their effects on urinary $\mathrm{Ca}$ losses, high intakes of both $\mathrm{Na}$ and protein increase dietary $\mathrm{Ca}$ requirements (Shortt \& Flynn, 1990; Cashman \& Flynn, 2003; Dawson Hughes, 2003). 


\section{Recommended calcium intakes}

Traditionally, daily $\mathrm{Ca}$ requirements have been estimated by a factorial approach. This practice involves estimating the average physiological requirement for absorbed $\mathrm{Ca}$ derived from balance data and adjusting for incomplete utilisation and variation in requirements among individuals and in the bioavailability of $\mathrm{Ca}$ among food sources. This approach is subject to considerable uncertainty, as is evident from the wide variation in estimates of daily $\mathrm{Ca}$ requirements made by different expert authorities. For example, the US and UK authorities have established very different recommendations for Ca intake (National Research Council, 1989; Department of Health, 1991; see Table 1). Much of this divergence arose as a result of different interpretations of available data, e.g. different estimates of absorption efficiencies and obligatory losses of $\mathrm{Ca}$ were used by the two authorities (Cashman \& Flynn, 1999).

More recently, the US Food and Nutrition Board (Institute of Medicine, 1997) established recommendations for daily $\mathrm{Ca}$ intake for different population groups, principally using data from metabolic balance studies to develop a non-linear regression model to predict the lowest value of intake at which mean maximal $\mathrm{Ca}$ retention is attained. This approach is based on the principle that maximising the $\mathrm{Ca}$ reserve in the skeleton is required in order to maximise skeletal strength, and that an adequate $\mathrm{Ca}$ intake is needed to achieve and preserve these geneticallydetermined upper limits of both skeletal size and density (Institute of Medicine, 1997). A major limitation of this approach is the limited balance data available, and this shortage of data resulted in the establishment of an 'adequate intake' rather than a recommended dietary allowance, since no estimate of average requirement could be derived (Table 1).

\section{Bone structure and function}

Bone is a specialised connective tissue that provides mechanical support for the body, facilitating muscle action and locomotion, and protecting the vital inner organs. Bone consists of a mineral phase of crystals of hydroxyapatite $\mathrm{Ca}_{10}\left(\mathrm{PO}_{4}\right)_{6}(\mathrm{OH})_{2}$ and other ions, an organic phase (osteoid) of collagen fibres, and a ground substance formed by glycoproteins and proteoglycans (Prentice et al. 2003). Three cell types produce and maintain bone:

- osteoblasts (bone-forming cells), which secrete osteoid and modulate the crystallisation of hydroxyapatite;

- osteoclasts (bone-resorbing cells), which are responsible for the resorption of bone for the repair of bone surfaces and the remodelling of bone;

- osteocytes, which are osteoblasts that have become embedded within the mineralised regions of bone and are involved in the sensing and translation of information about the internal bone environment.

There are two different types of bone: cortical (compact) bone, which is a thick and dense layer of calcified tissue that forms the outer surfaces of most bones and the shafts of the long bones; cancellous (trabecular) bone, which has a spongy appearance and consists of a lattice of thin calcified
Table 1. Recommended calcium intakes in the USA and UK ${ }^{\star}$

\begin{tabular}{|c|c|c|c|c|c|}
\hline \multicolumn{2}{|c|}{ US RDA (1989) } & \multicolumn{2}{|c|}{ UK RNI (1991)‡ } & \multicolumn{2}{|c|}{ US AI (1997) } \\
\hline $\begin{array}{l}\text { Age-group } \\
\text { (years) }\end{array}$ & $(\mathrm{mg} / \mathrm{d})$ & $\begin{array}{l}\text { Age-group } \\
\text { (years) }\end{array}$ & $(\mathrm{mg} / \mathrm{d})$ & $\begin{array}{l}\text { Age-group } \\
\text { (years) }\end{array}$ & $(\mathrm{mg} / \mathrm{d})$ \\
\hline $0-0.5$ & 400 & $0-1$ & 525 & $0-0.5$ & 210 \\
\hline $0-0.5$ & 600 & & & $0 \cdot 5-1$ & 270 \\
\hline $1-3$ & 800 & $1-3$ & 350 & $1-3$ & 500 \\
\hline $4-6$ & 800 & $4-6$ & 450 & $4-8$ & 800 \\
\hline $7-10$ & 800 & $7-10$ & 550 & & \\
\hline $11-14 \mathrm{M}$ & 1200 & $11-14 \mathrm{M}$ & 1000 & $9-13 \mathrm{M}$ & 1300 \\
\hline $15-18 \mathrm{M}$ & 1200 & $15-18 M$ & 1000 & $14-18 \mathrm{M}$ & 1300 \\
\hline $11-14 \mathrm{~F}$ & 1200 & $11-14 \mathrm{~F}$ & 800 & $9-13 \mathrm{~F}$ & 1300 \\
\hline $15-18 \mathrm{~F}$ & 1200 & $15-18 \mathrm{~F}$ & 800 & $14-18 \mathrm{~F}$ & 1300 \\
\hline $19-24$ & 1200 & $19-50$ & 700 & $19-30$ & 1000 \\
\hline $25-50$ & 800 & & & $31-50$ & 1000 \\
\hline$>51$ & 800 & $>50$ & 700 & $>50$ & 1200 \\
\hline Pregnancy & 1200 & Pregnancy & $\mathrm{NI}$ & $\begin{array}{c}\text { Pregnancy } \\
\leq 18 \\
19-50\end{array}$ & $\begin{array}{l}1300 \\
1000\end{array}$ \\
\hline Lactation & 1200 & Lactation & +550 & $\begin{array}{c}\text { Lactation } \\
\leq 18 \\
19-50\end{array}$ & $\begin{array}{l}1300 \\
1000\end{array}$ \\
\hline
\end{tabular}

RDA, recommended dietary allowances; RNI, reference nutrient intake; $\mathrm{Al}$ adequate intake; $\mathrm{M}$, males; $\mathrm{F}$, females; $\mathrm{NI}$, no increment.

*Estimates of Ca requirements refer to males and females unless stated otherwise.

†Based on a factorial approach (National Research Council, 1989).

$\ddagger$ Based on a factorial approach (Department of Health, 1991).

$\S$ Based principally on maximal Ca retention (Institute of Medicine, 1997).

trabeculae, and is found at the ends of long bones and within flat bones and the vertebrae. Cortical bone has $80-90 \%$ of its volume calcified, while in cancellous bone the corresponding value is only $15-25 \%$. The main function of cancellous bone is regarded as metabolic, whereas the role of cortical bone is predominantly structural (Prentice et al. 2003).

Bone turnover is central to maintenance of the structural function of the skeleton. It is a cyclical process whereby the skeleton undergoes continual renewal by a phased sequence of bone resorption followed by bone formation, processes which are coupled but separated in time, resulting in the modelling of growing bone and the remodelling of existing tissue (Kanis, 1991).

Bone acts as a metabolic reservoir of $\mathrm{Ca}$ for the maintenance of extracellular homeostasis. The concentration of $\mathrm{Ca}^{2+}$ in blood serum is maintained within narrow limits $(2 \cdot 3-2 \cdot 75 \mathrm{mmol} / \mathrm{l})$ by the concerted action of the three calciotropic hormones, parathyroid hormone, 1,25dihydroxyvitamin $\mathrm{D}$ and calcitonin. When serum $\mathrm{Ca}^{2+}$ concentration falls $\mathrm{Ca}^{2+}$-sensing receptors on the parathyroid glands detect the change and stimulate an increase in parathyroid hormone secretion. Parathyroid hormone acts on bone to release $\mathrm{Ca}$ and on the kidney to reduce urinary $\mathrm{Ca}$ excretion and increase the production of 1,25-dihydroxyvitamin $\mathrm{D}$. In turn, 1,25-dihydroxyvitamin $\mathrm{D}$ acts on the intestine to increase $\mathrm{Ca}$ absorption and on bone to further release $\mathrm{Ca}$. Increases in serum $\mathrm{Ca}^{2+}$ are reversed by calcitonin, which is secreted by the thyroid gland, and by negative feedback by 1,25-dihydroxyvitamin $\mathrm{D}$ on parathyroid hormone secretion (Cashman \& Flynn, 1999; Prentice et al. 2003). 


\section{Bone development}

In human subjects bone mass increases during childhood and adolescence, and from birth until the age of about 20 years $\mathrm{Ca}$ accumulates in the skeleton at an average rate of $150 \mathrm{mg} / \mathrm{d}$. Acquisition rates are highest in infancy and during the pubertal growth spurt, and are lower during the other periods of childhood. Linear growth stops at the end of puberty, but bone mass continues to increase for some time afterwards, reaching a peak during young adulthood. The age at which peak bone mass is achieved varies between different regions of the body and different populations. After peak bone mass has been achieved there is a slow decline in bone mass. This decline is accelerated in women following the menopause. The rates of postmenopausal bone mineral loss average 1-2\%/year in cortical bone and 2-3\%/year in cancellous bone (Prentice et al. 2003).

$\mathrm{Ca}$ is one of the primary bone-forming minerals. At birth an infant has approximately $20-30 \mathrm{~g} \mathrm{Ca}$ and by maturity the Ca mass is approximately $1200 \mathrm{~g}$, of which approximately $99 \%$ is in the bones and teeth (Prentice \& Bates, 1993). Nutritionally, therefore, adequate $\mathrm{Ca}$ intake is critical to the achievement of optimal peak bone mass and modifies the rate of bone loss associated with ageing.

\section{Osteoporosis}

The internationally-agreed description of osteoporosis is a systemic skeletal disease characterised by low bone mass and microarchitectural deterioration of bone tissue, with a consequent increase in bone fragility and susceptibility to fracture (World Health Organization, 1994). The disorder is a major health problem through its relationship with these fractures, which typically occur at three skeletal sites, the hip, wrist and spine. It has been estimated from incidence rates derived in North America that a lifetime risk of a fragility fracture at one of these three sites among white women aged 50 years is approximately $40 \%$, with a comparable risk of $13 \%$ among white men. Taking into account sites other than the hip, spine and distal forearm, the lifetime risk among women aged 50 years could be as high as $70 \%$ (Melton et al. 1992). Hip fractures lead to an overall reduction in survival of approximately $15 \%$, and the majority of excess deaths occur within the first 6 months following the fracture. Fractures are also associated with considerable morbidity, necessitating hospitalisation in most cases, with an average length of hospital stay approaching $30 \mathrm{~d}$. Hip fractures account for $>90 \%$ of the enormous health service budget spent on osteoporosis (Prentice et al. 2003).

An estimated $1.7 \times 10^{6}$ hip fractures occurred throughout the world in 1990. As a result of the increasing population and increased life expectancy, that number is expected to be $>6 \times 10^{6}$ by 2050 . Currently, the majority of hip fractures occur in North America and Europe, but demographic shifts over the next 50 years will lead to large increases in the number of elderly in Asia, South America and Africa. Consequently, there will be a shift in the burden of the disease from the developed to the developing world. Approximately $75 \%$ of hip fractures are expected to occur in the developing world by the year 2050 (World Health Organization, 1999).

\section{The relationship between bone mineral density and fracture risk}

The ultimate determinants of fragility fracture are bone strength and trauma. Bone strength is related to the quality of bone, its architecture and its mass. In older adults these characteristics correlate closely with bone mineral density (BMD), measured by dual-energy x-ray absorptiometry or related methods (Prentice et al. 2003). For this reason, the World Health Organization (1994) has a working definition of osteoporosis in terms of BMD relative to the young adult mean:

- osteoporosis, a value for BMD of $\geq 2.5$ SD below the young adult mean (T-score $\leq-2 \cdot 5)$;

- low bone mass (osteopenia), a value for BMD $>1$ SD below the young adult mean, but $<2.5$ SD below this value (T-score $<-1$ and $>-2 \cdot 5$ ).

Several prospective studies have now demonstrated that for older adults BMD measurement predicts future fracture among women (World Health Organization, 1994). One large study (Cummings et al. 1993) reported a 2.6-fold increase in the age-adjusted risk of hip fracture with each 1 SD decrease in femoral neck density for women aged 65 years followed for a 2-year period. Women with a BMD in the lowest quartile therefore had an $8 \cdot 5$-fold greater risk of hip fracture than those in the highest quartile. A metaanalysis by Marshall et al. (1996) confirmed that the risk of fracture increases by approximately 2-fold for each $1 \mathrm{SD}$ decrease in BMD. Although fracture risk is substantially lower among men than among women at any given age, the relationship between BMD and fracture risk lies on the same curve for each gender (De Laet et al. 1997). Fracture risk also increases with age, independently of BMD, to the same extent in both genders (De Laet et al. 1997), which may be related to changes in bone quality and bone turnover, or non-skeletal functions such as muscle strength or balance.

The bone mineral mass that accumulates at the end of the growth period in human subjects, the peak bone mass, is considered to be a major determinant of the risk of osteoporotic fractures in later life (World Health Organization, 1994). The reason is that for adults $>50$ years bone mass at the time of measurement reflects the combined effects of peak bone mass achieved in young adult life and subsequent bone loss. Although BMD at any age is a predictor of bone strength and fracture risk at that age (Goulding et al. 2001; Oleson et al. 2002), the indication that BMD predicts osteoporotic fracture risk in old age is based on studies conducted in older adults. The evidence that this relationship can be extrapolated to young subjects is weak, and the extent to which a change in BMD in children and young adults, caused by a change in diet or lifestyle, can predict a change in fracture risk in later life remains undetermined (Prentice et al. 2003).

Part of the variation in peak bone mass between individuals is related to inherited characteristics (60-70\%) and part to environmental factors acting during foetal life, childhood and/or adolescence (30-40\%; Prentice, 2001). 


\section{Bone turnover, bone mass and fracture risk}

The rate of bone formation and bone resorption, the balance of which over time ultimately determines bone mass, may be assessed by measurement of biochemical markers (Eastell et al. 1993). Biochemical markers for monitoring bone turnover all rely on the measurement, in serum or urine, of enzymes or matrix proteins synthesised by osteoblasts or osteoclasts that spill over into body fluids, or of osteoclast-generated degradation products of the bone matrix itself. Serum levels of skeletal alkaline phosphatase and osteocalcin are currently the most convincing markers of bone formation, while the most useful markers of bone resorption are all products of collagen degradation (e.g. pyridinium cross-links or peptides associated with crosslinking at either the $\mathrm{N}$-terminal or C-terminal ends) that may be measured in urine; Cashman \& Flynn, 1999).

It is now recognised that an increased rate of bone turnover in adults may be a risk factor for fracture (Riggs et al. 1996), partly because it exacerbates bone loss (Hansen et al. 1991). Conversely, a reduced rate of bone turnover may lower risk of fracture by slowing the rate of bone loss in later life (Riggs et al. 1996). Bone turnover is an important determinant of BMD after menopause and low BMD is associated with high bone turnover (Garnero et al. 1996; Scariano et al. 1998). High rates of bone turnover are also associated with a disruption of the trabecular network, leading to a loss of connectivity that is not necessarily reflected in a decrease in bone mass (Parfitt, 1984).

Prospective studies have shown an increased risk of osteoporotic fracture with increased rate of bone turnover, independent of bone density, in women at the time of the menopause (Hansen et al. 1991; Riis et al. 1995) and in elderly women (Garnero et al. 1996). The risk of hip fracture is increased approximately two-fold, independently of BMD, in elderly women with values for resorption markers exceeding the reference range for premenopausal women.

In children and adolescents a reduced rate of bone turnover is associated with increased BMD (Johnston et al. 1992; Slemenda et al. 1997; Dibba et al. 2000).

\section{Calcium interventions in older adults}

There have been more than twenty randomised controlled trials of the effect of Ca supplementation on bone (density) in the decades following the menopause. These trials have been reviewed by a number of authors (Dawson-Hughes, 1991; Institute of Medicine, 1997; Nordin, 1997; Prentice, 1997; Department of Health, 1998).

Almost all these studies showed a small beneficial trend in BMD for the Ca-treated subjects. In the great majority of these studies this trend was significant at one or more skeletal sites (e.g. the forearm, spine, proximal femur or total body). For example, supplementation studies of postmenopausal women showed that an increase in $\mathrm{Ca}$ intake reduces bone loss at the hip (Dawson-Hughes et al. 1990; Nelson et al. 1991; Reid et al. 1993; Chevalley et al. 1994; Prince et al. 1995), especially for subjects with a low habitual Ca intake (Dawson-Hughes et al. 1990). However, a number of studies indicated that increases in $\mathrm{Ca}$ intake have little effect on spinal bone mineral in older women (Nelson et al. 1991; Chevalley et al. 1994; Prince et al. 1995).

The benefits of $\mathrm{Ca}$ intervention appear to be more marked in late post-menopausal life than at the peri-menopause (Dawson-Hughes et al. 1990), although some studies have also found beneficial effects in this latter group (Elders et al. 1991). It may be that the greater variation in rates of bone loss in peri-menopausal women obscures the relatively small effect of $\mathrm{Ca}$ supplementation. However, $\mathrm{Ca}$ contributes to the effectiveness of hormone-replacement therapy and Nieves et al. (1998), in a review of clinical trials of hormone-replacement therapy, concluded that a high $\mathrm{Ca}$ intake potentiates the positive effect of oestrogen on bone mass at all skeletal sites, and perhaps that of calcitonin on bone mass of the spine.

A number of studies have suggested that the beneficial effect of $\mathrm{Ca}$ is most marked in the first year of treatment, particularly at sites that consist predominantly of cancellous bone (Reid et al. 1995). The mechanism of this effect is probably that it causes a fall in circulating parathyroid hormone concentrations, which decreases the number of bone remodelling units on the surface of cancellous bone. However, there is also evidence of a smaller residual positive effect on BMD of about $0.25 \%$ /year after the first year (Reid et al. 1995), which, if it were to continue over a number of years, would result in a marked cumulative benefit on BMD and a potentially reduced fracture risk.

There is only limited evidence for an effect of $\mathrm{Ca}$ intervention on fracture risk in older adults. Three studies have reported a significant effect of $\mathrm{Ca}$ on fracture incidence (Chevalley et al. 1994; Reid et al. 1995; Recker et al. 1996). When all randomised clinical trials reporting fracture events are combined, the use of $\mathrm{Ca}$ supplements was associated with a $35 \%$ decrease in vertebral fracture risk and a somewhat smaller effect on non-vertebral fractures (Kanis, 1999). However, these studies should be interpreted with caution, since they were relatively small, with limited power to detect the effects of $\mathrm{Ca}$ supplementation on fractures.

Three studies have been reported in which $\mathrm{Ca}$ was coadministered with vitamin D to elderly subjects. Chapuy et al. (1994) demonstrated a reduction of more than onequarter in non-vertebral and hip fracture rates in a cohort of 3000 elderly women given $20 \mu \mathrm{g}$ vitamin D and $1200 \mathrm{mg} \mathrm{Ca}$ daily studied over a period of 3 years, a finding which was confirmed recently (Chapuy et al. 2002). Dawson-Hughes et al. (1997) demonstrated a reduction of more than half in non-vertebral fracture rates in 400 older men and women randomised to receive Ca $500 \mathrm{mg}$ plus $17 \cdot 5 \mu \mathrm{g}$ vitamin D daily, or to receive a placebo. It is not possible to determine whether the $\mathrm{Ca}$, the vitamin $\mathrm{D}$ or the combination were responsible for the outcome of these studies. The effect on fracture rates of vitamin D supplementation alone is unclear, since two large studies of vitamin $\mathrm{D}$ intervention in older adults have reported conflicting results (Heikinheimo et al. 1992; Lips et al. 1996). Overall, the findings indicate a major reduction in morbidity in the elderly when combined $\mathrm{Ca}$ and vitamin $\mathrm{D}$ therapy is used. 


\section{Calcium intervention studies in children and adolescents}

A number of published studies of $\mathrm{Ca}$ supplementation in children and adolescents have observed increases in bone mineral content and BMD of $2-6 \%$ in response to supplementation with $\mathrm{Ca}$ salts, depending on the skeletal site (Johnston et al. 1992; Lloyd et al. 1993, 1996; Andon et al. 1994; Lee et al. 1994, 1995, 1996, 1997; Bonjour et al. 1997, 2001; Nowson et al. 1997; Slemenda et al. 1997; Specker et al. 1997; Dibba et al. 2000, 2002; Stear et al. 2003). In these trials Ca supplementation was provided in various salt forms such as citrate malate (Johnston et al. 1992; Lloyd et al. 1993), carbonate alone (Lee et al. 1994, 1995; Dibba et al. 2000), carbonate combined with gluconolactate (Nowson et al. 1997), or phosphate from milk extract (Bonjour et al. 1997, 2001). In another prospective controlled study a positive effect on bone mineral mass was seen after milk supplementation (Cadogan et al. 1997). In general, this effect of Ca supplements on bone mineral content and BMD has not been associated with alterations in skeletal size, although in some studies increases at the lumbar spine have been reported, indicating anabolic effects on the skeleton (Lee et al. 1995; Bonjour et al. 1997, 2001; Dibba et al. 2000).

There is no obvious relationship between the magnitude of the increase in bone mineral achieved in different studies and the customary $\mathrm{Ca}$ intake of the study group or the level of Ca supplements used (Prentice, 1995). It is possible that the response may be greater in, or limited to, children with lower Ca intake (Bonjour et al. 1997) or who are at specific stages of development (Johnston et al. 1992; Lloyd et al. 1996; Nowson et al. 1997), but the data are not consistent (Lee et al. 1994, 1995; Lloyd et al. 1996; Dibba et al. 2000).

An important consideration in the interpretation of longitudinal $\mathrm{Ca}$ intervention studies is the phenomenon of the 'bone remodelling transient', a term used to describe the suppression of bone remodelling that is seen with $\mathrm{Ca}$ supplementation and that results in a one-time initial gain in bone mass over the first 3-12 months after increasing Ca intake (Frost, 1973). It is thought to reflect completion of osteoblast activity after the inhibition of osteoclastic activity by the increased Ca intake (Slemenda et al. 1997). It is transient in so far as much of, if not all, the gain in bone mass appears to be sustained only for the duration of $\mathrm{Ca}$ supplementation.

This outcome has been observed on follow up of some $\mathrm{Ca}$ supplementation trials in children, which showed that differences in bone mass between subjects and controls disappeared after supplementation ceased (Fehily et al. 1992; Lee et al. 1996, 1997; Slemenda et al. 1997). However, not all studies observed this outcome and some studies showed that at least some of the differences persist for between 1 and $3 \cdot 5$ years after withdrawal of supplement (Bonjour et al. 1997, 2001; Dibba et al. 2002). For example, results of a follow-up study of 8-year-old prepubertal girls done 3.5 years after the end of a 48 -week randomised double-blind placebo-controlled intervention with milkextracted calcium phosphate $(850 \mathrm{mg} \mathrm{Ca} / \mathrm{d})$ incorporated into various foods showed that the increase in the overall BMD of the six skeletal sites observed during the intervention was still highly significant $(P=0 \cdot 012$; Bonjour et al. 2001). The authors concluded that supplementation with this form of Ca can lead to a sustained increase in bone mass accrual that lasts beyond the end of supplementation. However, it is not clear whether the effect is just speeding up maturation with earlier attainment of peak bone mass, or whether the accrual of bone mass is shifted onto a different trajectory resulting in attainment of a greater peak bone mass at maturity. More research is required to determine the long-term effect on bone mineral status of $\mathrm{Ca}$ intervention in growing individuals.

\section{Adequacy of calcium intakes}

In the absence of reliable indicators of nutritional adequacy for $\mathrm{Ca}$, estimates of $\mathrm{Ca}$ deficiency are based largely on adequacy of dietary intake relative to estimated requirements (Flynn \& Cashman, 1999). This approach is complicated by the lack of agreement between expert groups on requirements for $\mathrm{Ca}$. However, even taking the lower end of the range of estimated requirements as the yardstick, there is considerable evidence that there is a significant prevalence of dietary inadequacy for $\mathrm{Ca}$ in some population groups in many countries (Cleveland et al. 1996; Department of Health, 1998; Gregory et al. 2000; Hannon et al. 2001). For example, in UK women 13-18\% of 14-34 year olds and 8-15\% of those $>65$ years have habitual $\mathrm{Ca}$ intakes less than the lower reference nutrient intake, a level below which intake is almost certainly deficient (Department of Health, 1998). Using the method of Carriquiry (1999) to estimate prevalence of inadequacy, $45 \%$ of 11-18-year-old girls in the UK fail to consume the average requirement for Ca (Gregory et al. 2000). Data from the North/South Food Consumption Survey in Ireland show that $23 \%$ of 18-64-year-old women fail to achieve the average requirement for $\mathrm{Ca}$ (Hannon et al. 2001).

\section{Conclusions}

While inadequate dietary $\mathrm{Ca}$ intake in childhood and adolescence can impair bone development, it is unclear whether the commonly observed increase in bone mass resulting from dietary $\mathrm{Ca}$ supplementation is of lasting benefit, leading to the optimisation of peak bone mass in early adulthood. Resolution of this uncertainty will require longitudinal studies on the relationship between $\mathrm{Ca}$ intake throughout the early years of childhood and attainment of peak bone mass in early adulthood.

In older adults inadequate dietary $\mathrm{Ca}$ accelerates bone loss and may contribute to osteoporosis. Ca supplementation of the usual diet in post-menopausal women and older men has been shown to reduce the rate of loss of BMD at a number of sites over periods of 1-2 years. However, the extent to which increasing $\mathrm{Ca}$ intake reduces fracture risk needs to be determined in studies of adequate size with bone fracture as an outcome. There is good evidence to indicate that a marked reduction in fracture risk can be achieved in the elderly using combined $\mathrm{Ca}$ and vitamin $\mathrm{D}$ therapy. 
There is considerable disagreement between expert groups on the daily $\mathrm{Ca}$ intake levels that should be recommended, reflecting the uncertainty in the data used for establishing Ca requirements. Even allowing for disagreements on recommended intakes, evidence indicates that dietary $\mathrm{Ca}$ intake is inadequate for the maintenance of bone health in a substantial proportion of some population groups, particularly adolescent girls and older women.

\section{Acknowledgement}

This work was carried out with financial support from the European Commission Quality of Life Fifth Framework Programme, QLK1-CT 1999-000752.

\section{References}

Andon MB, Lloyd T \& Matkovic V (1994) Supplementation trials with calcium citrate malate: Evidence in favour of increasing the calcium RDA during childhood and adolescence. Journal of Nutrition 124, 1412S-1417S.

Bonjour JP, Carrie AL, Ferrari S, Clavien H, Slosman D, Theintz G \& Rizzoli R (1997) Calcium-enriched foods and bone mass growth in prepubertal girls - a randomized, double-blind, placebo-controlled trial. Journal of Clinical Investigation 99, 1287-1294.

Bonjour JP, Chevalley T, Ammann P, Slosman D \& Rizzoli R (2001) Gain in bone mineral mass in prepubertal girls 3.5 years after discontinuation of calcium supplementation: a follow-up study. Lancet 358, 1208-1212.

Cadogan J, Eastell R, Jones N \& Barker ME (1997) Milk intake and bone mineral acquisition in adolescent girls - randomised, controlled intervention trial. British Medical Journal 315, $1255-1260$.

Carriquiry AL (1999) Assessing the prevalence of nutrient inadequacy. Public Health Nutrition 2, 23-33.

Cashman KD \& Flynn A (1999) Optimal nutrition: calcium, magnesium and phosphorus. Proceedings of the Nutrition Society 58, 477-487.

Cashman KD \& Flynn A (2003) Sodium effects on bone and calcium metabolism. In Nutritional Aspects of Bone Health [S New and J-P Bonjour, editors]. London: Royal Society of Chemistry (In the Press).

Chapuy MC, Arlot ME, Delmas PD \& Meunier PJ (1994) Effect of calcium and cholecalciferol treatment for three years on hip fractures in elderly women. British Medical Journal 308, 1081-1082.

Chapuy MC, Pamphile R, Paris E, Kempf C, Schlichting M, Arnaud S, Garnero P \& Meunier PJ (2002) Combined calcium and vitamin $\mathrm{D}_{3}$ supplementation in elderly women: confirmation of reversal of secondary hyperparathyroidism and hip fracture risk: the Decalyos II study. Osteoporosis International 13, 257-264.

Chevalley T, Rizzoli R, Nydegger V, Slosman D, Rapin CH, Michel JP, Vasey H \& Bonjour JP (1994) Effects of calcium supplements on femoral bone mineral density and vertebral fracture rate in vitamin-D-replete elderly patients. Osteoporosis International 4, 245-252.

Cleveland LE, Goldman JD \& Borrud LG (1996) Data Tables: Results from USDA's 1994 Continuing Survey of Food Intakes by Individuals and 1994 Diet and Health Knowledge Survey. Beltsville, MD: Agriculture Research Service, US Department of Agriculture.

Cummings SR, Black DM, Nevitt MC, Browner W, Cauley J, Ensrud K, Genant HK, Palermo L, Scott J \& Vogt TM (1993)
Bone density at various sites for prediction of hip fractures. Lancet 341, 72-75.

Dawson-Hughes B (1991) Calcium supplementation and bone loss: a review of controlled clinical trials. American Journal of Clinical Nutrition 54, 274S-280S.

Dawson-Hughes B (2003) Interaction of dietary calcium and protein in bone health in humans. Journal of Nutrition 133, $852 \mathrm{~S}-854 \mathrm{~S}$.

Dawson-Hughes B, Dallal GE, Krall EA, Sadowski L, Sahyoun N \& Tannenbaum S (1990) A controlled trial of the effect of calcium supplementation on bone density in postmenopausal women. New England Journal of Medicine 323, 878-883.

Dawson-Hughes B, Harris SS, Krall EA \& Dallal GE (1997) Effect of calcium and vitamin D supplementation on bone, density in men and women 65 years of age or older. New England Journal of Medicine 337, 670-676.

De Laet CE, van Hout BA, Burger H, Hofman A \& Pols HA (1997) Bone density and risk of hip fracture in men and women: cross-sectional analysis. British Medical Journal 26, 221-225.

Department of Health (1991) Dietary Reference Values for Food Energy and Nutrients for the United Kingdom. Report on Health and Social Subjects no. 41. London: H.M. Stationery Office.

Department of Health (1998) Nutrition and Bone Health with Particular Reference to Calcium and Vitamin D. Report on Health and Social Subjects no. 49. London: The Stationery Office.

Dibba B, Prentice A, Ceesay M, Mendy M, Darboe S, Stirling DM, Cole TJ \& Poskitt EM (2002) Bone mineral contents and plasma osteocalcin concentrations of Gambian children 12 and 24 mo after the withdrawal of a calcium supplement. American Journal of Clinical Nutrition 76, 681-686.

Dibba B, Prentice A, Ceesay M, Stirling DM, Cole TJ \& Poskitt EME (2000) Effect of calcium supplementation on bone mineral accretion in Gambian children accustomed to a low-calcium diet. American Journal of Clinical Nutrition 71, 544-549.

Eastell R, Robins SP, Colwell T, Assiri AM, Riggs BL \& Russell RG (1993) Evaluation of bone turnover in type I osteoporosis using biochemical markers specific for both bone formation and bone resorption. Osteoporosis International 3, 255-260.

Elders PJ, Netelenbos JC, Lips P, van Ginkel FC, Khoe E, Leeuwenkamp OR, Hackeng WH \& van der Stelt PF (1991) Calcium supplementation reduces vertebral bone loss in perimenopausal women: a controlled trial in 248 women between 46 and 55 years of age. Journal of Clinical Endocrinology and Metabolism 73, 533-540.

Fehily AM, Coles RJ, Evans WD \& Elwood PC (1992) Factors affecting bone density in young adults. American Journal of Clinical Nutrition 56, 579-586.

Flynn A \& Cashman KD (1999) Calcium. In The Mineral Fortification of Foods, pp. 18-53 [R Hurrell, editor]. Leatherhead, Surrey: Leatherhead Food Research Association.

Frost HM (1973) The origin and nature of transients in human bone remodeling dynamics. In Clinical Aspects of Metabolic Bone Disease, pp. 124-137 [B Frame, AM Parfitt and H Duncan, editors]. Amsterdam, The Netherlands: Excerpta Medica.

Garnero P, Hauser E, Chapuy MC, Marcelli C, Grandjean H, Muller C, Cormier C, Breard G, Meunier PJ \& Delmas PD (1996) Markers of bone turnover predict hip fractures in elderly women. The EPIDOS prospective study. Journal of Bone and Mineral Research 11, 1531-1538.

Goulding A, Jones IE, Taylor RW, Williams SM \& Manning PJ (2001) Bone mineral density and body composition in boys with distal forearm fractures: a dual-energy x-ray absorptiometry study. Journal of Pediatrics 139, 509-515.

Gregory J, Lowe S, Bates CJ, Prentice A, Jackson LV, Smitherts G, Wenlock R \& Farron M (2000) National Diet and Nutrition 
Survey: Young People Aged 4-18 years. London: The Stationery Office.

Hannon E, Kiely M, Harrington KE, Robson P, Strain JJ \& Flynn A (2001) The North/South Ireland Food Consumption Survey: Mineral intakes in 18-64 year old adults. Public Health Nutrition 4, 1081-1088.

Hansen M, Overgaard K, Riis B \& Christiansen C (1991) Role of peak bone mass and bone loss in postmenopausal osteoporosis: 12 year study. British Medical Journal 303, 961-964.

Heaney RP (1997) The roles of calcium and vitamin D in skeletal health: an evolutionary perspective. Food, Nutrition and Agriculture no. 20, pp. 4-12. Rome: FAO.

Heikinheimo RJ, Inkovaara JA, Harju EJ, Haavisto MV, Kaarela RH, Kataja JM, Kokko AM, Kolho LA \& Rajala SA (1992) Annual injection of vitamin D and fractures of aged bones. Calcified Tissue International 51, 105-110.

Institute of Medicine (1997) Calcium. Dietary Reference Intakes: Calcium, Magnesium, Phosphorus, Vitamin D, and Fluoride, pp. 4/1-4/57. Washington, DC: National Academy Press.

Johnston CC Jr, Miller JZ, Slemenda CW, Reister TK, Hui S, Christian JC \& Peacock M (1992) Calcium supplementation and increases in bone mineral density in children. New England Journal of Medicine 327, 82-87.

Kanis JA (1991) Calcium requirements for optimal skeletal health in women. Calcified Tissue International 49, S33-S41.

Kanis JA (1999) The use of calcium in the management of osteoporosis. Bone 24, 279-290.

Lee WTK, Leung SSF, Cheng JCY, Wang SH, Xu YC \& Zeng W$P$ (1995) Effects of calcium supplementation and subsequent withdrawal on bone acquisition of Chinese children. Proceedings of the 7th Asian Congress of Nutrition F-61-03, p. 343. Beijing, China: Chinese Nutrition Society.

Lee WTK, Leung SSF, Leung DMY \& Cheng JCY (1996) A follow-up study on the effects of calcium-supplement withdrawal and puberty on bone acquisition of children. American Journal of Clinical Nutrition 64, 71-77.

Lee WTK, Leung SSF, Leung DMY, Wang SH, Xu YC, Zeng WP \& Cheng JCY (1997) Bone mineral acquisition in low calcium intake children following the withdrawal of calcium supplement. Acta Paediatrica 86, 570-576.

Lee WTK, Leung SSF, Wang SH, Xu YC, Zeng W-P, Lau J, Oppenheimer SJ \& Cheng JCY (1994) Double-blind, controlled calcium supplementation and bone mineral accretion in children accustomed to a low-calcium diet. American Journal of Clinical Nutrition 60, 744-750.

Lips P, Graafmans WC, Ooms ME, Bezemer PD \& Bouter LM (1996) Vitamin D supplementation and fracture incidence in elderly persons - a randomized, placebo-controlled clinical trial. Annals of Internal Medicine 124, 400-406.

Lloyd T, Andon MB, Rollings N, Martel JK, Landis JR, Demers LM, Eggli DF, Kieselhorst K \& Kulin HE (1993) Calcium supplementation and bone mineral density in adolescent girls. Journal of the American Medical Association 270, 841-844.

Lloyd T, Martel JK, Rollings N, Andon MB, Kulin K, Demers LM, Eggli D, Kieselhorst K \& Chinchili VML (1996) The effect of calcium supplementation and Tanner stage on bone density, content and area in teenage women. Osteoporosis International 6, 276-283.

Marshall D, Johnell O \& Wedel H (1996) Meta-analysis of how well measures of bone mineral density predict occurrence of osteoporotic fractures. British Medical Journal 312, 1254-1259.

Melton LJ, Chrischilles EA, Cooper C, Lane AW \& Riggs BL (1992) How many women have osteoporosis? Journal of Bone and Mineral Research 7, 1005-1010.

National Research Council (1989) Calcium. Recommended Dietary Allowances, 10th ed., pp.174-184. Washington, DC: National Academy Press.
Nelson ME, Fisher EC, Dilmanian FA, Dallal GE \& Evans WJ (1991) A 1-y walking program and increased dietary calcium in postmenopausal women: effects on bone. American Journal of Clinical Nutrition 53, 1304-1311.

Nieves JW, Komar L, Cosman F \& Lindsay R (1998) Calcium potentiates the effect of estrogen and calcitonin on bone mass review and analysis. American Journal of Clinical Nutrition 67 , $18-24$.

Nordin BEC (1997) Calcium and osteoporosis. Nutrition 13, 664-686.

Nowson CA, Green RM, Hopper JL, Sherwin AJ, Young D, Kaymakci B, Guest CS, Smid M, Larkins RG \& Wark JD (1997) A co-twin study of the effect of calcium supplementation on bone density during adolescence. Osteoporosis International 7, 219-225.

Oleson CV, Busconi BD \& Baran DT (2002) Bone density in competitive figure skaters. Archives of Physical and Medical Rehabilitation 83, 122-128.

Parfitt AM (1984) Age-related structural changes intrabecular and cortical bone: Cellular mechanisms and biomechanical consequences. Calcified Tissue International 36, S123-S128.

Prentice A (1995) Calcium requirements in children. Nutrition Reviews 53, 37-40.

Prentice A (1997) Is nutrition important in osteoporosis? Proceedings of the Nutrition Society 56, 357-367.

Prentice A (2001) The relative contribution of diet and genotype to bone development. Proceedings of the Nutrition Society $\mathbf{6 0}$, $1-8$.

Prentice A \& Bates CJ (1993) An appraisal of the adequacy of dietary mineral intakes in developing countries for bone growth and development in children. Nutrition Research Reviews 6, 51-59.

Prentice A, Bonjour J-P, Branca F, Cooper C, Flynn A, Garabedian M, Müller D, Pannemans D \& Weber P (2003) Process for the assessment of scientific support for claims on foods (PASSCLAIM): Bone health and osteoporosis. European Journal of Nutrition 42, Suppl. 1, I28-I49.

Prince R, Devine A, Dick I, Criddle A, Kerr D, Kent N, Price R \& Randell A (1995) The effects of calcium supplementation (milk or tablets) and exercise on bone density in postmenopausal women. Journal of Bone and Mineral Research 10, 1068-1075.

Recker RR, Hinders S, Davies KM, Heaney RP, Stegman MR, Lappe JM \& Kimmel DB (1996) Correcting calcium nutritional deficiency prevents spine fractures in elderly women. Journal of Bone and Mineral Research 11, 1961-1966.

Reid IR, Ames RW, Evans MC, Gamble GD \& Sharpe SJ (1993) Effect of calcium supplementation on bone loss in post-menopausal women. New England Journal of Medicine 328, 460-464.

Reid IR, Ames RW, Evans MC, Gamble GD \& Sharpe SJ (1995) Long-term effects of calcium supplementation on bone loss and fractures in postmenopausal women - a randomised controlled trial. American Journal of Medicine 98, 331-335.

Riggs BL, Melton LJ III \& O'Fallon WM (1996) Drug therapy for vertebral fractures in osteoporosis: Evidence that decreases in bone turnover and increases in bone mass both determine antifracture efficacy. Bone 18, 197S-201S.

Riis BJ (1995) The role of bone loss. American Journal of Medicine 98, Suppl. 2A, 29-32.

Scariano JK, Vanderjagt DJ, Thacher T, Isichei CO, Hollis BW \& Glew RH (1998) Calcium supplements increase the serum levels of crosslinked N-telopeptides of bone collagen and parathyroid hormone in rachitic Nigerian children. Clinical Biochemistry 31, 421-427.

Shortt C \& Flynn A (1990) Sodium-calcium inter-relationships with specific reference to osteoporosis. Nutrition Research Reviews 3, 101-115. 
Slemenda CW, Peacock M, Hui S, Zhou L \& Johnston CC (1997) Reduced rates of skeletal remodeling are associated with increased peak bone mineral density during the development of peak skeletal mass. Journal of Bone and Mineral Research 12, 676-682.

Specker BL, Beck A, Kalkwarf H \& Ho M (1997) Randomized trial of varying mineral intake on total body bone mineral accretion during the first year of life. Pediatrics 99, E121-E127.

Stear SJ, Prentice A, Jones SC \& Cole TJ (2003) Effect of a calcium and exercise intervention on the bone mineral status of 16-18-y- old adolescent girls. American Journal of Clinical Nutrition 77, 985-992.

World Health Organization (1994) Assessment of Fracture Risk and its Application to Screening for Postmenopausal Osteoporosis. Technical Report Series no. 843. Geneva: WHO.

World Health Organization (1999) Interim report and recommendations of the World Health Organization Task Force for Osteoporosis. Osteoporosis International 10, 259-264. 